Nordisk Judaistik - Scandinavian Jewish Studies

Vol. 17, No. 1-2, 1996, 75-83

Judiska nordbor eller nordiska judar?

\title{
Svante Lundgren
}

\section{Pargas}

En befolkningsgrupp som alltid varit starkt kollektivistisk är den judiska. Att den överhuvudtaget överlevt den 1900-åriga förskingringen - den s.k. diasporan - beror på att den som en liten minoritet avvikit från omgivningen, hårt hållit på sin särart och kännetecknats av stark inre konformitet. Detta skedde dels av eget fritt val, dels p.g.a. tvång.

I modern tid har dock bilden ändrats. Den judiska upplysningen - haskalan - gav upphov till judar som långt hade anammat västerländsk kristen bildning och kultur. Typexemplet på en dylik kompromiss mellan anpassning till upplysningsidealen och fasthållandet vid det judiska är Moses Mendelsohn (1729-86). Enstaka judar kunde nu göra sig gällande $\mathrm{i}$ den kristna världen men det förutsatte att de $\mathrm{i}$ varje fall $\mathrm{i}$ viss mån gjorde avkall på sin judiskhet. I efterdyningarna till den franska revolutionen blev det möjligt för hela det judiska samfundet att bryta dess långvariga kulturella isolering.

I och med att dörrarna till västerländsk kultur och bildning öppnas för judarna sker det också en splittring inom den tidigare ändå rätt så enhetliga judenheten i Europa. Frågan om hur judisk religion skall förhålla sig till det moderna samhället delar judarna och så uppstår riktningarna ortodoxa, konservativa och liberala. Samtidigt lockar helt areligiösa ideologier många judar, inte minst den unga socialismen. Sionismen, som nu uppstår som en organiserad rörelse, är också till övervägande delar areligiös.

I slutet av 1800-talet har därför en europeisk jude - till skillnad från sina förfäder några generationer tidigare - många möjligheter att leva som jude $\mathrm{i}$ Europa. Han kan hålla fast vid sin judiska religion, men utöva den på många olika sätt. Han kan glömma sitt judiska arv och ge sig hän åt sina nya av emancipationen öppnade möjligheter och rentav konvertera. Han kan engagera sig i den socialistiska rörelsen, antingen utifrån en judisk plattform (t.ex. bundism) eller utan specifikt judiskt predikament. Eller han kan verka för upprättandet av en egen judisk stat, ett engagemang som ofta kombinerades med en socialistisk övertygelse.

I Norden har judarna alltid utgjort en mycket liten minoritet. Det har därför varit naturligt att betona det kollektiva och söka stöd och styrka i gemenskapen. Samtidigt har judarna självfallet varit utsatta för ett tryck från det omgivande samhället och majoritetskulturen. Under 1900-talet har de assimilatoriska tendenserna stadigt ökat, men under de senaste decennierna har dock - inte minst i Sverige - utvecklingen tagit en annan riktning och den judiska medvetenheten har klart stärkts. ${ }^{1}$

$1 \quad$ Ett exempel på extrem assimilation utgör Gert Bonniers år 1933 i ett slutet sällskap framförda förslag om en frivillig judisk "förintelse", vilken skulle ske "genom assimilation i den svenska folkkroppen med tillhjälp av blandäktenskap”. Se Hansson 1988. 
Efter denna mycket summariska historiska bakgrundsteckning vill jag kort reflektera över skillnaderna mellan judisk och kristen individualism. I dagens Norden är den livsåskådningsmässiga individualismen mycket stark. Är man religiös så är man privatreligiös. Om man tror på Gud uppger man snabbt att man tror på sitt eget sätt, inte så som kyrkan lär (många som säger så har egentligen en mycket vag uppfattning om vad kyrkan lär).

Inom judendommen förekommer inget motsvarande. Det beror på två fakta. För det första är judendomen inte bara en religion utan också en etnisk tillhörighet. Att vara jude är inte så mycket att tillhöra en trosgemenskap som att tillhöra en ödesgemenskap, att ha del $i$ ett folks historia och traditioner. Det är alltså fullt möjligt att ha vilken som helst uppfattning om Gud, ja t.o.m. att helt förneka hans existens och ändå vara helt och fullt jude. I själva verket är det just det många judar i dagens Norden gör. Den judiska renessans i Norden som omnämndes ovan har i första hand ägt rum på ett etno-nationellt och kulturellt plan, inte på ett religiöst plan.

Den andra orsaken till att judisk individualism inte handlar om heretiska trosuppfattningar är att den judiska religionen fäster större vikt vid handlingar (både etiska och kultiska) än vid tro.

Så länge man delar den judiska gemenskapen, efterlever judendomens etiska regler och upprätthåller de judiska traditionerna, anses man vara en "god jude" även om tron uteblir. ${ }^{2}$

När en kristen alltså funderar på ifall hans tro på Gud stämmer överens med kyrkans officiella lära, grubblar kanske en jude på om hans utövande av judiska seder är i linje med judendomens traditioner. Skillnaden mellan de judiska riktningarna är inte i första hand dogmatisk, utan praktisk. Hur mycket av de gamla ceremonierna och reglerna skall man hålla fast vid? Hur långt kan gamla seder och bruk moderniseras utan att något omistligt går förlorat? Det är dessa frågor - och inte dogmatiska spetsfundigheter - som är centrala i judisk debatt.

Som tidigare nämnts upplever vi en judisk renessans i Norden i dag. Det finns många judar som är mycket lite eller inte ett dugg religiösa, som följer de judiska sederna $\mathrm{i}$ större eller mindre utsträckning, men som har en mycket stark judisk identitet och som känner stark tillhörighet till sitt kollektiv, judenheten, det judiska folket. Orsakerna till detta är många. En viktig orsak är vårt århundrades största civilisatoriska katastrof, judeförintelsen, holocaust.

Att efter Auschwitz vägra erkänna sin judiskhet, det är att ge Hitler och hans bödlar en posthum seger. ${ }^{3}$

$2 \quad$ Ilicki, 135.

3 Dencik, 67. Den som först uttryckte denna tanke var den judiske filosofen Emil Fackenheim. 
I denna artikel skall jag undersöka två självbiografier av judar i Norden. Böckerna ifråga är Jo Benkow, Fra synagogen til løvebakken, och Boris Grünstein, Jude i Finland. Hur beskriver de sitt eget förhållande till det judiska? Hur uttrycker de spänningen mellan att vara medlem av den judiska minoriteten och samtidigt lojal medborgare $\mathrm{i}$ ett nordiskt sekulariserat kristet land?

Benkow är till yrket fotograf, men har gjort sig känd som politiker. Han har varit långvarig medlem av den norska riksdagen, Stortinget, ordförande för partiet Høyre och Stortingspresident. Grünstein har utfört sitt professionella livsverk som företagare i pälsbranschen, men är också känd för allmänheten som framstående revyförfattare. Till det yttre visar de båda stora likheter. Benkow är framstående revyförfattare. Till det yttre visar de båda stora likheter. Benkow är född 1924, Grünstein 1917, bägge härstammar från östjudar, bägge tillhör mycket små judiska minoriteter i ungefär lika stora länder och bägge präglades starkt av sina upplevelser under andra världskriget.

Deras självbiografier är dock mycket olika. Benkow skriver ledigt, tidvis humoristiskt och med en befriande självironi. Hans framställning är speciell såtillvida att den är koncentrerad på barndomen. Om sina upplevelser under kriget efter sin flykt från Norge 1942 skriver han ingenting, om sin politikerbana efter kriget endast i det sista kapitlet. Barndomsfamiljens medlemmar beskrivs ingående (det finns kapitelrubriker som Min far, Min bror och Onkel Herman), men huruvida han själv är gift och har familj lämnar han inget besked om. Grünsteins framställning är i huvudsak rätlinjigt kronologisk och mycket personlig. Sitt privatliv lämnar han generöst ut, de amorösa eskapaderna spelar rentav en framträdande roll i boken. Som revyförfattare var Grünstein en skicklig skribent och texten är inte bara lätt, utan lättsinnig och underfundigt humoristisk. Bokens undertitel är ju Galghumoristiska berättelser.

Både Benkow och Grünstein kommer från heljudiska familjer. Bägge gick i judisk skola. För Benkows del var det fråga om en kompletterande skola, dvs. han gick $i$ en vanlig skola men två gånger $\mathrm{i}$ veckan åkte han efter skolan till synagogan för att få undervisning i den judiska religionsskolan. Detta pågick i fem år och ledde fram till Bar Mitzwa. Undervisningen var vid denna tid - på 1930-talet - tydligen inte på så god pedagogisk nivå eftersom Benkow kan skriva: "Den selsomme undervisningen jeg fikk der, fortoner seg den dag i dag som et sammenhengende mareritt." (Benkow 1985, 85). Sin Bar Mitzwa omtalar han dock med stor värme. (op. cit., 97-99).

Den judiska skolan i Helsingfors, där Grünstein gick, var däremot en normal heldagsskola med allmänna lika väl som judiska ämnen. Den hade på Grünsteins tid tre förberedande och sex högre klasser. Vilket intryck den judiska undervisningen gjorde omtalar Grünstein inte. Han nöjer sig med att berätta anekdoter från skolan (Grünstein, 16-20). Läraren i judiska ämnen betecknar han som inkompetent, så av allt att döma gjorde undervisningen inget djupare intryck.

Huruvida man $\mathrm{i}$ det Grünsteinska hemmet följde judiska seder lämnar författaren osagt. Benkow återigen ägnar flera kapitel åt att för läsarna beskriva de olika judiska 
ritualerna och traditionema. När det gäller koscherföreskrifterna säger Benkow att det $\mathrm{i}$ hans barndomshem skedde en gradvis uppluckring. (Benkow 1985, 69).

Om de båda författarnas bakgrund kan alltså sammanfattningsvis sägas, att bägge hade en klar judisk identitet, men ingendera var religiös. Grünstein följde av allt att döma inte särskilt noggrant judiska regler, Benkow i något högre men dock minskande grad.

Sedan kom andra världskriget.

De finländska judarnas öde under andra världskriget har åtnjutit avsevärt intresse. Inte en enda finländsk jude - däremot nog några judiska flyktingar - utlämnades till Nazityskland. ${ }^{4}$ De finländska judarna stred lojalt i Finlands båda krig, i fortsättningskriget ironiskt nog som allierade med Nazityskland. För sin lojalitet med Finland har judarna fătt nationens tack och för sitt skydd av sina judar har Finland fått judenhetens tack. ${ }^{5}$

Under vinterkriget befriades Grünstein från tjänstgöring av hälsoskäl. Under fortsättningskriget tjänstgjorde han $\mathrm{i}$ armén, huvudsakligen som tolk vid förhör av ryska krigsfångar. I sin bok beskriver han utförligt det dilemma säkert alla Finlands judar upplevde under detta krig. Om den egna sidan - och därmed också Nazityskland - vinner är det slut med judarna, om däremot den andra sidan vinner kan det gå illa för Finland. Slutet blev ju sedan lyckligt: Hitler förlorade och Finland bevarade sin självständighet.

Klart är att Hitlers härjningar och krigets fasor stärkte Grünsteins samhörighet med judenheten, även om han själv under kriget mest umgicks med likasinnade, dvs. antinazistiska icke-judar.

För Norges judar var andra världskriget en betydligt större katastrof. Efter den tyska ockupationen i april 1940 försvårades judarnas liv på olika sätt. Allt kulminerade i oktober 1942 då hundratals judar arresterades för att snart deporteras till utrotningsläger på kontinenten (främst Auschwitz). Sammanlagt deporterades 760 norska judar, av vilka endast 25 överlevde. Lite fler judar - drygt 900 - lyckades dock rädda sig genom att fly till Sverige. ${ }^{6}$

Jo Benkow hörde - liksom hans far, morbror och bror med familj - till dem som lyckades fly till Sverige. Däremot deporterades och avrättades hans mor, syster och två fastrar, liksom många av hans vänner. Eftersom Benkow i sin självbiografi koncentrerar

4 Om denna episod har det skrivits två böcker: Suominen 1979 och Rautkallio 1985. Den senare finns också i en något utvidgad engelsk version, Rautkallio 1987, som framprovocerat en motreaktion, Cohen \& Svensson 1995.

5 Torvinen, 161-167.

6 För en ingående presentation av dessa händelser, se Mendelsohn, 13-335. 
sig på förkrigstiden beskriver han inte krigsårens händelser mer än mycket ytligt. ${ }^{7}$ Att det var en katastrof som för alltid satt prägel på hans liv står i varje fall klart. Benkows bok är optimistisk och ljus. Därför frossar han inte i tragiska händelser. Ett stråk av sorg och vemod går dock igenom boken och kommer ibland till uttryck, t.ex. när han beskriver sin fars död:

Han døde i 1955 nær 70 år gammel Min bror og jeg fikk være hos ham til han utåndet. På sitt dødsleie anropte han min mor. Det hjalp like lite da som ved så mange tidligere anledninger i mere bevisst tilstand. (Benkow 1985, 181).

En judisk angelägenhet som varit viktig för både Benkow och Grünstein är staten Israel. Grünstein, som säger sig aldrig ha trott på uttrycket "Guds utvalda folk", trodde dess mer på staten Israel. Han gjorde sig känd som en stor Israelvän som i många debatter försvarade Israels existens och förklarade Mellanösternproblematiken. Han talade vid flera solidaritetsfester, en gång rentav i Knesset. Hans engagemang för Israel tar sig uttryck också i de vanliga anklagelserna om massmedias partiskhet i konflikten (Grünstein, 240-241) samt $i$ ett smått nedsättande sätt att beskriva araber. ${ }^{8}$

Benkows beskrivning av staten Israel är - $\mathrm{i}$ likhet med tendensen $\mathrm{i}$ hela hans bok mer en objektiv framställning av statens tillkomst och villkor än en redogörelse för vad han personligen företagit sig. Han säger sig aldrig ha övervägt emigration eftersom han känner sig så hemma i det norska samhället. Trots det har staten Israels upprättelse betytt mycket för honom.

Mange jøder over hele verden rettet ryggen, gikk litt rankere og opptrådte med større sikkerhet og frimodighet. Nå hadde man ikke lenger den samme nedarvede følelse av å leve på nåde. (Benkow 1985, 162).

Som vi hittills har sett är viktiga element $\mathrm{i}$ samhörigheten med det judiska både för Benkow och för Grünstein upplevelsen av ödesgemenskap under kriget samt känslan och engagemanget för staten Israel. Men hur är det då med deras inställning till den judiska religionen?

Grünstein behandlar religiösa frågor oerhört sparsamt i sin bok. Han berätter inget om hemmets religiösa vanor, beskrivningen av den religiösa fostran i skolan är - som ovan konstaterats - knapp och sin egen Bar Mitzwa nämner han inte alls (däremot nog sin sons). Efter kriget var Grünstein en tid anställd av den judiska församlingen i Helsing-

$7 \quad$ Benkow har behandlat den tyska ockupationen av Norge också senare, Benkow 1990. Detta är dock inte en självbiografisk text, utan en essä om vad ockupationsåren haft för betydelse för det politiska livet i Norge. Judarnas öde omnämns kort (92-93), men det är nog mer politikern Benkow än juden Benkow som här kommer till tals.

8 Direkt fel i sak har Grünstein då han i raljerande ton talar om araben som stenar en otrogen hustru "trots att han kan ha tiotals (kursivering S. L.) andra hustrur som står i kö" (Grünstein, 229). 


\section{Svante Lundgren}

fors, men han yppar inget om dess gudstjänstliv eller annan religiös verksamhet. Man skall naturligtvis inte dra alltför långtgående slutsatser av sådant som inte sägs, men det torde stå klart, att Grünstein var en areligiös jude. Då han dessutom antyder, att han inte tror på något liv efter döden (Grünstein, 244) är det kanske av hänsyn till de troende judarna som han har avstått från att diskutera religiösa frågor i sin bok.

Benkow däremot tar tjuren vid hornen och har rubricerat ett av sina kapitel $\mathrm{Om}$ Gud (Benkow 1985, 153-156). Här deklarerar sig Benkow som icke-troende med respekt för dem som har ett äkta religiöst liv och för dem som har klarat av att bevara tron. "Det greide ikke jeg." (op. cit., 155).

Det ögonblick då barnatron slutgiltigt försvann fastställer Benkow till november 1942 då hans mor och många andra deporterades till Tyskland. Visserligen säger han, att han senare i livet litet modifierat den spontana gudsförnekelse som den tragedin utlöste, men ändå kvarstår det grundläggande problemet.

Hvis det er slik at de individuelle menneskeskjebner er styrt og fullbrakt af Gud, da må Vår Herre ha henfalt til mye slurv og langvarige perioder af distraksjon. Det er den eneste holdbare forklaringen på at en rettferdig Gud har tillat så mye urett, ja, direkte frastøtende og grusomt. (Benkow 1985, 154).

Det är den klassiska teodicé-problematiken som här kommer till uttryck. Trots den på sina ställande lätt raljerande tonen ger kapitlet också uttryck för ett visst vemod. Man får intrycket att Benkow gärna skulle vilja tro. Han kan bara inte. "Jeg skulle ønske jeg tvilte eller at noen kunne overbevise meg om at jeg tar feil." (Benkow 1985, 155).

Samtidigt bekänner han sig klänga fast vid något slags diffus allmänreligiositet, en "viss tro på en udefinert høyere makt". (op. cit., 155). Han kommer m.a.o. mycket nära den i de nordiska samhällena så allmänna privatreligiositeten, även om han inte har någon stark tro på den heller.

Som vi har sett beskriver Grünstein inte särskilt ingående sitt förhållande till judisk religion och tradition. Det är därför omöjligt att på basen av hans bok säga något om hur hans judiska identitet utvecklats. Benkow lämnar däremot klara besked om detta.

Benkow växte - som vi har konstaterat - upp i ett hem där man rätt strikt följde judiska traditioner. Men själv började han känna sig alltmer främmande inför detta.

I mine eldre guttedager vokste det frem både tross og uvilje i meg. Jeg reagerte stadig sterkere og mere uforsonlig på det jeg mente ikke var stort annet enn meningsløse besvergelser og virkelighetsflukt. (Benkow 1985, 70).

Ännu när han efter krigsåren återvänder hem säger han sig ha upplevt en väldig distans till det rituellt judiska. (Benkow 1985, 14).

I takt med den ökande distansen till det judiska stärks strävan efter "normalisering", att bli som alla andra norrmänn. Benkow skriver att han ofta totalt glömt bort vilken dag 
Jom Kippur infaller eftersom han haft så bråttom att "overbevise både omverdenen og meg selv om hvor norsk og til forveksling lik alle andre jeg var." (Benkow 1985, 96).

På ett annat ställe skriver han:

Personlig drømte jeg aldri noen gang om noe annet enn å forbli nordmann med den sterke tilknytning jeg hadde til norsk tradisjon, kultur og levemåte. Det er til heder og ære for det land og det folk som jeg regner som mitt, at det er blitt slik. (Benkow 1985, 162).

När Benkow är festtalare på 17. mai-firandet 1959 upplever han hur han har uppnått det han hoppats på, “å få være nordmann på like vilkår." (Benkow 1985, 143).

Men det framgår också klart att den judiska identitet som Benkow tidvis haft komplex för, upplevt stor distans till, ibland önskat ersätta med en norsk, så småningom blir naturlig och självklar för honom.

Men mit motstand mot sedvane, skikk og bruk har avtatt betraktelig med årene. Alt som var og fortsatt er har sin egenverdi. Selv følger jeg ikke jødisk skikk og bruk. Jeg har intet forhold til den jødiske religion, men jeg vil gjerne være jøde. (Benkow, 1985, 70).

När Benkow så sent som 1985 fick veta att hans farfar haft en stark anknytning till synagogan säger han sig av någon oförklarlig anledning ha blivit mycket upprymd av denna nyhet. (Benkow 1985, 25). Jag tror man kan hävda, att Benkow inbegriper sig själv när han om den judiska tillhörigheten skriver:

For svært mange er det et spørgsmål om lojalitet, respekt for tradisjon og forfedre, og en forpliktelse til å praktisere og vedkjenne seg sin jødedom, slik at den ikke skal gå tapt. (Benkow $1985,72)$.

Vad det är som har gjort att Benkow nu känner starkare anknytning till det judiska än vad han gjorde i sin ungdom, det säger han inte. Det kan naturligtvis vara fråga om en allmänmänsklig upplevelse. När man blir äldre söker man sig gärna tillbaka till sina rötter. Men jeg tror också att specifika händelser i Benkows liv har spelat en roll. Det tragiska öde som drabbade hans familj ger honom säkert en stark önskan att fortsätta att vara jude trots att han inte omfattar den judiska religionen och trots att många judiska seder känns främmande för honom. Den lojalitet och respekt för förfäderna - som citatet ovan talar om - känner han säkert extra starkt eftersom en stor del av hans förfäder dödades just därför att de var judar. Men detta är - som sagt - endast sådant jag utläser mellan raderna. Benkow talar inte explicit om detta.

Avslutningsvis vill jag ge en karaktäristik av de båda självbiografierna utifrån begreppsparet kollektivt - individuellt.

Grünsteins bok har en titel som är mycket kollektiv. En memoarbok vid namn Jude $i$ Finland kunde i princip varenda jude i Finland ha skrivit. Trots det är boken mycket individualistisk, den beskriver precis en judes liv i Finland, nämligen författarens. Kollektiviteten tar sig uttryck $\mathrm{i}$ den mån denna levnad är representativ för hela gruppen. Vilket den till vissa stycken är. Många judar i Finland har liksom Grünstein varit i 
affärsbranschen och hans upplevelser under kriget och känsla för Israel är troligtvis rätt allmänna för hans generation judar $\mathrm{i}$ Finland.

Med Benkows memoarbok är det precis tvärtom. Titeln är individualistisk men innehållet mycket kollektivistiskt. En självbiografi med titeln Fra synagogen til løvebakken kan skrivas endast av en norsk-judisk riksdagsman - løvebakken är ett annat ord för det norska parlamentet, Stortinget - och sådana torde det inte ha funnits andra än Benkow. Ändå är stora delar av boken judiskt allmängods. I flera kapitel beskriver författaren judiska seder och traditioner på ett allmänt plan, ibland exemplifierat med den egna familjens efterlevnad av dessa.

Benkows bok kunde mycket väl haft titeln Jude $i$ Norge och Grünsteins Från pälsbutiken till Knesset.

\section{Litteratur}

Benkow, Jo, Fra synagogen til løvebakken, Oslo 1985.

Benkow, Jo, "Fellesskap og motstand i krig og fred. 9. april i politisk lys", in: Jo Ben kow og Ole Kristian Grimnes, Vendepunkt - 9. april $i$ vår bevissthet, Oslo 1990, 75144.

Cohen, William B. och Svensson, Jörgen, "Finland and the Holocaust", in: Holocaust and Genocide Studies, 9, 1995, 70-93.

Dencik, Lasse, "Hemma i hemlösheten", in: Jackie Jakubowski (red.), Judisk identitet, Stockholm 1993, 48-70.

Grünstein, Boris, Jude i Finland. Galgenhumoristiska berättelser, Borgå 1988.

Hansson, Svante, “Antisemitisim, assimilation och judisk särart. Svenskjudisk elitdebatt vid Hitlers maktövertagande 1933”, in: G. Broberg, H. Runblom \& M. Tydén (red.), Judisk liv i Norden, Acta Universitatis Upsaliensis, Uppsala 1988, 307-327.

Ilicki, Julian, "Judiskhet som nationalitet", in: Jackie Jakubowski (red.), Judisk identitet, Stockholm 1993, 133-140.

Mendelsohn, Oskar, Jødernes historia i Norge gjennom 300 år, Bd. 2, 1940-1985, OsloBergen-Stavanger-Troms $\varnothing, 2$. utg. 1987.

Rautkallio, Hannu, Ne kahdeksan ja Suomen omatunto. Suomesta 1942 luovutetut juutalaispakolaiset, Espoo 1985.

Rautkallio, Hannu, Finland and the Holocaust. The rescue of Finland's Jews, New York 1987.

Suominen, Elina, Kuoleman laiva S/S Hohenhörn. Juutalaispakolaisten kohtalo Suomessa, Porvoo 1979.

Torvinen, Taimi, Kadimah. Soumen juutalaisten historia, Helsinki 1989. 


\section{Judiska nordbor eller nordiska judar?}

\section{Summary}

The Jews in Scandinavia have always been a small minority, where the own identity and the collective belonging have been important. During this century the Scandinavian Jews have become both more secularized and assimilated, and the extreme individualism of the surrounding society has influenced them also.

This essay deals with how the tension between being a member of a small Jewish minority and at the same time a loyal citizen of a secularized Christian country is reflected in two autobiographies by Scandinavian Jews: Boris Grünstein's Jude $i$ Finland (Jew in Finland) and Jo Benkow's Fra synagogen til lovebakken (From the synagogue to the parliament). Both authors are non-religious Jews who have a strong Jewish identity, strengthened by their experiences during World War Two and their affection for Israel. At the same time they are well integrated in society and feel at home in their countries. Their feeling of affinity with the Jewish community seems to have grown after a period of distance in younger years. 